\title{
$\infty$ \\ Sessão da Saudade em memória \\ do Acadêmico José Rodrigues Coura
}

\author{
por \\ José Carlos do Valle \\ Membro Titular, Academia Nacional de Medicina \\ jcvalle@uol.com.br
}

Senti-me muito lisonjeado ao ser convidado para homenagear o Acadêmico José Rodrigues Coura nesta Sessão da Saudade. Foi um homem muito especial e sua vida é repleta de aventuras e desbravamentos. Coura é natural de Taperoá, microrregião do Cariri, na Paraíba. Quando nasceu, em 15 de junho de 1927, a vila era formada por apenas três ruas: a rua da Frente, a de Trás e a do Meio. Os pais foram nascidos na regiáo e o seu avô materno, Neco Carneiro, ele considerava um verdadeiro cangaceiro. Aplicou um golpe num juiz da região e fugiu com um baú de dinheiro e casou-se com uma menina de 13 anos, avó do Coura. Neco Carneiro comprou imensas áreas de terras na região e loteou em lotes de $6 \mathrm{~km}$ por $8 \mathrm{~km}(48 \mathrm{~km} 2)$ que doou para os seus filhos, uma delas ao Lupércio, pai do Coura que nela desenvolveu uma fazenda.

Coura, quando pequeno, foi colega de curso primário de Ariano Suassuna no colégio da vila. Determinado dia, ele soube que Lampião iria invadir a vila de Taperoá.
Essas invasões eram cruéis, porque Lampião e seu bando impiedosamente matavam, roubavam e estupravam as mulheres.

O pai do Coura resolveu liderar a resistência à invasão com os habitantes armados. Após horas de espera o ataque não ocorreu. Soube-se depois que Lampião havia desistido por considerar que a vila náo valia a pena (segundo ele, era uma merda!). Foi uma decepção para o Coura e Ariano que estavam escondidos para ver o tiroteio.

Coura sempre falava com carinho e admiração pelo Ariano Suassuna que acabou indo para Recife e se formando em direito. Terminou por ser um dos mais celebrados escritores do país, além de dramaturgo, ensaísta, poeta e professor.

Lupércio transferiu a administração da fazenda para o Coura quando este tinha 16 anos de idade. No rompante da adolescência, ele achava que o pai era um incompetente pois a fazenda era pouco produtiva. $\mathrm{Na}$ verdade, descobriu depois que o pai não 
era incompetente, mas as terras áridas não propensas a serem produtivas. Coura resolveu fazer um beneficiamento no arroz e milho e a sua mãe, Ercília, fez uma fabriqueta de manteiga e queijos para vender.

Aos 17 anos foi incumbido pelo pai de vender três toneis de manteiga em Campina Grande. Em lá chegando, viu um caminhão estacionado que estava de partida com retirantes para o Rio de Janeiro. Após a venda dos toneis, resolveu comprar uma passagem com o motorista. Telegrafou, então, para o pai informando-o que estava de partida para o Rio e assim que pudesse lhe restituiria o dinheiro.

Ele veio no caminhão apinhado de gente que parou em Montes Claros, em Minas. Lá tomou um trem da Central do Brasil. Quando chegou em Madureira o trem pegou fogo e todos os passageiros abandonaram o trem, pulando na linha férrea.

Conseguiu chegar ao centro do Rio, onde se encontrou com uma irmá que lhe deu abrigo.

Após inúmeras atribulaçóes, prestou concurso e ingressou na então Faculdade Nacional de Medicina. Formou-se um pouco tarde aos 30 anos, quando foi colega de turma de Pietro Novellino e Léa CamiloCoura, com quem se casou. Acreditava que essa diferença de idade em relação a turma lhe deu certa vantagem por ser mais experiente. Dez anos depois prestou concurso para catedrático de doenças infecciosas e parasitárias da Faculdade Fluminense de Medicina sendo aprovado, e, aos 50 anos, conquistou a cátedra de DIP na Faculdade Nacional de Medicina da Universidade do Brasil, atual UFRJ.

Considerava fundamentais os três anos que passou no exército brasileiro, onde adquiriu uma certa disciplina. Todavia, o seu maior orgulho e realização plena foi ter ingressado na Fiocruz. Chora emocionado ao se referir a esta instituição onde foi chefe do Laboratório de Doenças Parasitária e Diretor do Instituto Oswaldo Cruz. Foi a sua grande paixão. Criou um serviço memorável de pós-graduação que formou centenas de especialistas. Quando se aposentou o serviço produzira mais de 400 trabalhos publicados em revistas de alto impacto.

Sempre teve tendência a ser um líder carismático e muito amado.

Coura chefiava uma missão no Rio Negro, na Amazônia, que tinha como escopo pesquisar principalmente malária e doença de Chagas, tendo produzido trabalhos memoráveis de repercussão internacional. Se considerava um verdadeiro nativo na região.

Quando iniciamos há cerca de dez anos os jantares no Iate Club do Rio de Janeiro após as sessóes da Academia, iniciativa do 
Coura, Adolpho Hoirisch, Mário Correa Lima e eu, tive a ideia de expandir para os demais acadêmicos, que faziam rodízio para a presença de cerca de 12 a 14 por jantar, número para ocupar a maior mesa redonda do clube. O Coura, sempre impagável, atraia a atenção de todos com suas histórias. Eu brincava com ele sobre as suas frequentes idas à floresta amazônica...

A Fiocruz gravou um vídeo de 31 minutos denominado "José Rodrigues Coura. O Tropicalista do Sertâo Fragmentos de uma vida", que recomendo a todos. Emocionante e imperdível.

Publicou seis livros médicos, com destaque ao seu tratado de referência nacional e em dois volumes: Dinâmica das Doenças Infecciosas e Parasitárias. Nos últimos anos produziu um outro livro extraordinário - Fundamentos das Doenças Infecciosas e Parasitárias, em associação com Nelson Gonçalves Pereira, um tratado intermediário à Dinâmica. Era para ser lançado na Academia, entretanto ele ficou doente e não conseguiu. Combinei com o Presidente Rubens Belfort que tão logo a pandemia permitisse e voltássemos as reuniôes presenciais, poderíamos fazer o lançamento do livro como uma homenagem ao Coura.

Duas frases em relação ao Coura ficam como um legado. A primeira: "Dos mestres você tem o exemplo, mas se aprende é com os alunos. Tudo que aprendi foi com meus alunos". Outra com relação a ele: "Transita confortavelmente entre castelos e casebres e sabe se comportar em qualquer um deles".

Falava que Taperoá deu três filhos ilustres: Ariano Suassuna, o músico Capiba - o mais conhecido compositor de frevos do país -, e o outro a modéstia o impedia de dizer. $\mathrm{Na}$ verdade, isso é incorreto. Ariano nasceu em João Pessoa na Paraíba e Capiba, em Surubim, Pernambuco. Desse modo, pode-se afirmar que José Rodrigues Coura é o mais ilustre dos taperoenses.

É um vencedor na vida como ele admite, tanto como médico, professor, pesquisador e nas amizades. Morreu feliz e plenamente realizado faltando uma semana para completar 94 anos em 22 de julho de 2021. 